Portland State University

PDXScholar

$5-5-1971$

\title{
Anxiety Level of Graduate Students in Social Work
}

Sophia Kouidou-Giles

Portland State University

George Albert McKee

Portland State University

Follow this and additional works at: https://pdxscholar.library.pdx.edu/open_access_etds

Part of the Personality and Social Contexts Commons, School Psychology Commons, and the Social Work Commons

Let us know how access to this document benefits you.

\section{Recommended Citation}

Kouidou-Giles, Sophia and McKee, George Albert, "Anxiety Level of Graduate Students in Social Work" (1971). Dissertations and Theses. Paper 1417.

https://doi.org/10.15760/etd.1416

This Thesis is brought to you for free and open access. It has been accepted for inclusion in Dissertations and Theses by an authorized administrator of PDXScholar. Please contact us if we can make this document more accessible: pdxscholar@pdx.edu. 
AN ABSTRACT OF THE THESIS OF Sophia Kouidou-Giles and George Albart Mckee for the Master of Social Work presented May 5, 1971.

Title: Anxiety Level of Graduate Students in Social lork

APPROVED BY MEMBERS OF THE TIIESIS COMNITTEE:

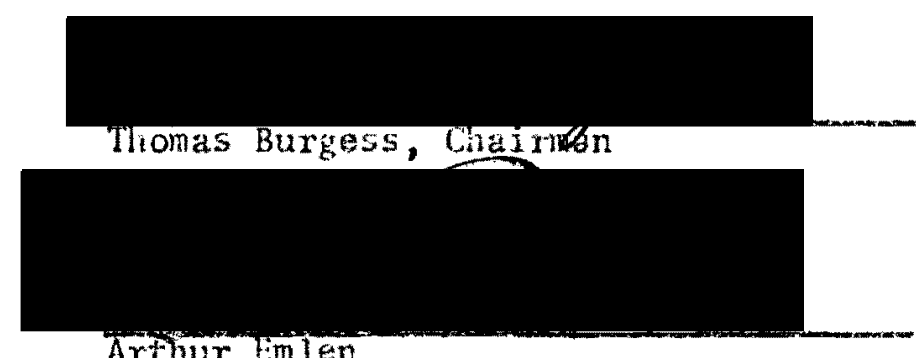

Arthur Emlen

This study was designed to deternine (1) the trend of anxiecy level of social work students, tem by term, over the acadomic year; (2) the cyclical trerd of arixiety. level of social work students within each texm and ( 3 ) the effects of age and sex on level of anxiety anong social work students.

Axiety was measured with the IPAT - 8 parallel Fom Anxiaty Battery. This test was adrinistored to twancy randonly salectad first yoar students in the School of Social Hork during the $1969-1970$ acadomic year at Portland State University. Data vas collected from six test administrations which took place at the beginning and the end of each tem. Analysis of varianca in a $2 \times 2 \times 2 \times 3$ factorial dasign simultaneousiy invostigated all. four variables.

Sone variation anong these variables and their interactions was found, but only the "time of quartex" main effect reached statistical 
significance. A cyclical pattern of anxiety following a high-in-thebeginning, low-at-the-end of each tem trend was observed. Anxiety, however, remained quite level over the three terms of the academic year. Nor was anxiety lovel related to differences in age or sex. These findings have led the authors to speculate that the uncertainty of a new situation at the beginning of each new term created more anxiety than did the final field evaluations, classroom examinations, papers or other outside influences such as the Kent State incidents etc., and that increased structuring at the beginning of each term might help to allay that anxiety.

Perhaps it could be said that each individual's role as a "social work graduate student" had a greater effect on his anxiety level than did sex, age, or important events not directly related to school expectations. 
ANXIETY LEVEL OF GRADUATE STUDENTS IN SOCIAL WORK

by

SOPHIA KOUIDOU-GILES

and

GEORGE ALBERT MCKEE

A thesis subnitted in partial fulfillnent of the requirements for the degree of

MASTER OF SOCIAL WORK

1

Portland State University

1971 
TO THE OFFICE OF GRADUATE STUDIES:

The members of the Committee apnrove the thesis of Sophia Kouidou-Giles and George Albert McKee presented May 5,1971 .

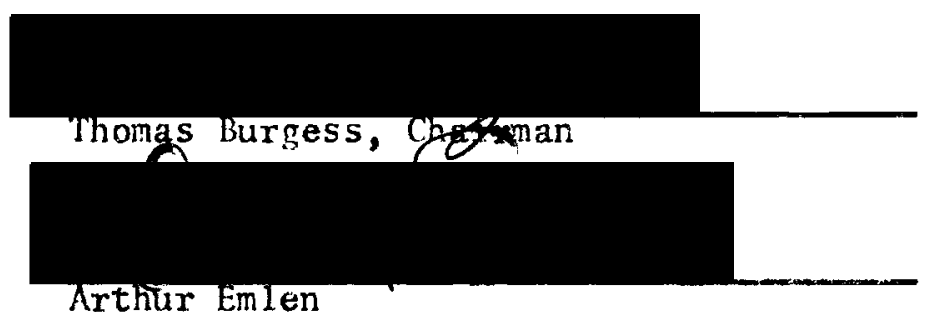

APPROVED:

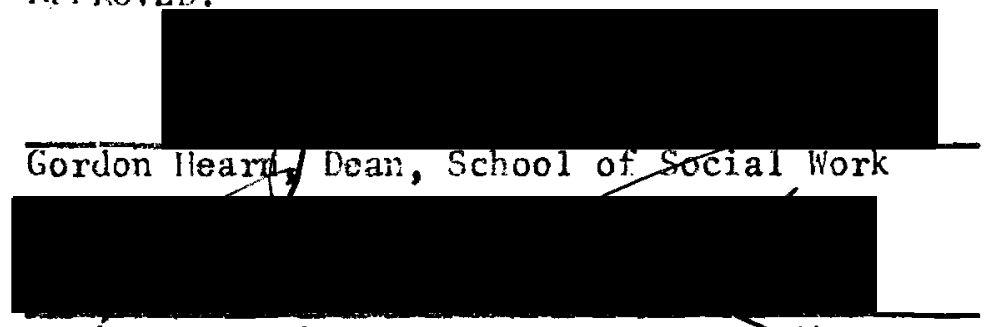

David T. Clark, Dean of Graduate Studies

May 5, 1971 


\section{ACKNOWLEDGEMENTS}

We wish to express our appreciation for the generous help from several faculty nembers of Portland State University.

First of all we wish to thank Dr. Thomas Burgess, our thesis advisor, for his assistance and encouragement throughout the entire project.

We would also like to express our gratitude to Dr. Arthur Emlen and Dr. Deane Clarkson for consulting with us on the statistical aspects of this study.

Our thanks also go to Mrs. Lillian Dickinson, Mrs, Lorna Lewis, as well as Mr. Albex Schmadick, who administered the tests to the students of the School of Social Work during the Fall and Winter terms.

Finally, we would like to acknowledge the cooperation of the class of 1970-1971 and the School of Social Work for their assistance and participation in this thesis project. 
TABLE OF CONTENTS

PAGE

ACKNONLEDGEMENTS ........................ i i

LIST OF TABLES ......................... vi

LIST OF FIGURES . . . . . . . . . . . . . . . . vii

CIIAPTER

I THE probleM ................... 1

Need for Study .............. 2

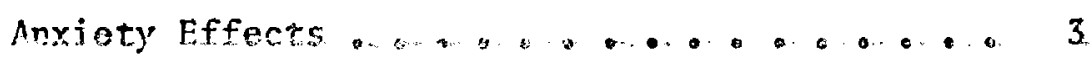

Effects on Student Learning . . ...... 5

Meaning of Auxiety ............. 5

How Anxiety is Produced.......... 8

Statement of the Problem ........... 11

II

METHODOLOGY •. . . . . . . . . . . . 12

General Design .. . . . . . . . . 12

Test Materials ............. 12

rype of Test

Description of Content

Development of Test

Reliability

Scoring and Nomis 
Administrative Procedures ......... 16

Variations in Procedure

Timing of Test Administration and Associated Events

Subjects .... . . . . . . . . . 23

Population Samnled

Sampling Method

Evaluation of the Sample

Statistical Design . . . . . . . 26

III

RESULTS ................... 27

Summary of Findings ........... 33

IV CONCLUSIONS .............. 34

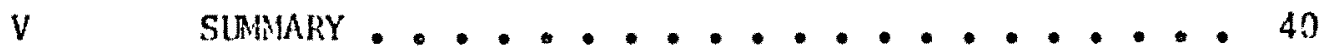

REFERENCES ....................... 42

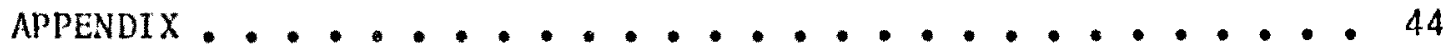




\section{LIST OF TABLES}

\section{TABLE}

PAGE

1 Population and Sample................... 25

2 Final Samule for Statistical Analysis . . . . . . 25

3 Mean Anxiety Scores of Sub-groups ........... 28

4 Analysis of Variance of Anxiety Test Scores . . . . . 29 


\section{LIST OF FIGURES}

FIGURES

1 Anxiety Scores of 1969-1970 for the Total Group ............... 27

2 Anxiety Scores for Male and Female Subjects ...... 30

3 Anxiety Scores for the Younger and Oider

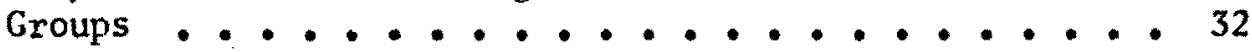


CHAPTER I

THE PROBLEM

Observations of the first year students of the School of Social Work during the rirst few weeks of the school year 1969-1970 suggested there was a common feeling of anxiety among tho students, During some of the initial functions involving students and faculty members, such as orientation, student body meetings and group conferences, the students asked many questions concerning their future activities in the School of Social hork. They were also exploring their roles and expectations for the practical field experience. The stucients seem to be attempting to make tangible the tasks that were ahead of them. Some of the typical questions that were being asked by them included, "What will be the content of this course?" "ilill it be necessary to read all of the bibliographies?" "How nany written assignments will be required to be tumed in?" "What tynes of cases and clients will we receive in the field placement?" "Will we have to write up all our processed recordings?" etc. These attenpts to clarify the students' roles and faculty expectations could be interpreted as manifestations of anxiety.

Various faculty members and field instructors expressed concern about this same phenumenon. There seemed to be beliefs among professors and field instructors that the pattern of anxiety anong the students would follow a certain path. This group theorized that anxiety would run higher during the fall term, particularly when the first assignments 
were due. After this point the level of anxiety would go down, but then gradually would go un to a peak near the erd of the first term. Those students who receive satisfactory field placement evaluations at the end of each term would have lower arixiety and vice versa. At the start of the second tem anxiety would be very high and then go down on a gradual level during the term as the students became more comfortable. Papers and other assignments and examinations would have a tendency to raise the anxiety level. The anxiety level would be at a peak at the time of all final examinations. During the Spring quarter anxiety would go up as the students determine in what thesis projects they would become involved. The general anxiety level of most students would lessen during the Spring quarter. The professors and field instructors incerviewed were in total agreement with these predictions. In short, they expected a general trend of lowering anxiety over the year, combined with recurrent cycles during each term with a peak at the end of each term.

\section{Need for Study}

There were several reasons for this area of study. First of all there is too much unreliability in casual observation and anecdotal evidence. More systematic observations would be needed to produce trustworthy information. Second, the question had possible important implications for student orientation. This could contribute in establishing programs and policies that would alleviate detrimental student anxiety. Third, anxiety is known to have an effect on student. performance. Several authors have presented views and supporting data on the relation of anxiety to student perfomance. 
Anxiety Effects

Anxiety can either have a motivating or inhibiting effect upon performance. Following are theories or statements concerning the inhibiting effect.

Tolman (1948) viewed anxiety from a cognitive viewpoint. He stated that a high level of motivation is accompanied by a "narrowing of the cognitive field." [p. 189] A highly motivated person may attend only to those cues which he expects to be useful in the attainment of his goals. If the task or problem is a novel or difficult one, his intense motivation may lead to his ignoring relevant information.

Krech and Crutchfield (1965) point out that "there are involuntary autonomic responses associated with anxiety which could interfere with execution of a task," [n. 293] The pianist may find it difficult to play when his hands are perspiring and his heart pounding and the actor may find his mouth so dry that he is incapable of delivering his lines. It is also possible that a highly anxious person's actions will become directed toward reducing his anxiety rather than performing the task. The student might start skipping class or not doing all of his assigned raading. The disruption in performance resulting from anxiety seems to be greatest for relatively difficult tasks. Studies by Montague (1953), Farbor and Spence (1953), and Raymond (1952), show that the superiority in rate of leaming of non-anxious subjects (as measured by the Taylor Manifest Anxiety Scale) increases with the difficulty of the muterial to be learned. Spiolberger (1962) has found that "students of low intellectual ability eam poor grades in college irrespective of the Taylor anxiety 
score, while anxious students in the middle range of ability obtained lower grades and a higher percentage of academic failure than nonanxious students of comparable ability. For the very superior students (with ACE scores over 150), however, anxiety appeared to faciiitate academic performance." [p. 425]

Along with this position by Spielberger, Krech and Crutchfield (1965) also take the position that anxiety can be a notivating effect. They claim that low levels of anxiety may lead to various constructive effects aiding goal attainment. Anxiety may induce intensified striving to overcome the barrier, or it may induce various kinds of adaptive readjustments to the situation, including the recognition of alternative paths to their goal, the substitution of the different and accessible goal and the rodefining of the whole situation so that a conflict, which brings about anxiety, is aliminated without further serious consequences.

Cattell (1963) presents three schools of thought which posit various effects of anxiety upon performance. These include that of the leaming theorist who considers anxiety as being the main drive to action, the clinical view expressed by Frank M. Burger, "that anxiety is a disorganizor of effective action and the psychoanalytic view that anxiety is a central problem in neurosis." [p. 98] Another explanation of how anxiety effects performance involves the supposition that a high level of motivation to attain a goal tends to be associated with anxiety which, in turn, impairs performance. 
Effects on Student Leaming

What about the assertion that anxiety impairs learning performance? There is considerable anecdotal and experimental evidence which suggests that this, in fact, is the case. On the anecdotal side there are the frequently heard stories about the student who was so frightened by the prospect of failing the examination that his mind went blank. In experiments it has been shown that when individuals are placed in a stressful situation designed to create anxiety, the performance tends to be lower than when the situation is not stressful. (Mckinney, 1933; Sears, 1937; Lantz, 1945; Alper, 1946; Williams, 1947; McClelland and Apicella, 1947; Mechanic, 1962; and Postman and Bruner, 1948). Grooms and Endlar (1960) found that "there is no direct significant relationship between test anxiety and academic achievement."

McKeachie (1951) concluded that "it appears that while anxiety may be a valuable motivating force it inhibits student performance if it cannot be resolved." [p. 158]

Meaning of Anxiety

In formulating a study of anxiety (student) one of the main problems is the various ways in which different professionals view this emotional state. This study is not an attempt to give a complete description of what and why anxiety exists in students. Nevertheless, several views will be presented and summarized.

The literature includes several theories of anxiety and related definitions. N1though much has been written on this subject, it is difficult to find a universally accepted definition, as the way in 
which it is defined appears to depend on the theory of anxiety preferred. Because of the complexity of the definition it was decided not to pursue a definite meaning for this study. Any one or all could be considered.

Let us consider the following authors.

Buss (1966) considers anxiety as a "neurotic reaction." [p. 50] He divides anxiety symptoms into four separate groupings. (1) "The somatic symptoms that largely reflect the over activity of the autonomic nervous system. (2) Cognitive symptoms that result from apprehensiveness, varying from nild worry to dread. (3) The affective symptoms which nove on the continuum of tense excitement to panic. (4) The motor symptoms which include observable behaviors such as tremor and unsteadiness, restlessness, etc." [pp. 53-55]

Sagebiel (1964) says that anxiety "is a reality of expression of an unconscious emotional force which has been built up over many years from childhood to adulthood, which in the normal individual results in caution. In the psycho-neurotic or psychotic individual anxiety results in a conscious knowledge but unwarranted fear of its physiological concomitants due to stimulation of the adrenal glends. One must distinguish between, No. 1, fear of an external reality situation, No. 2, apprehension which is the anticipation of the fear inspiring situation that may not occur, No. 3, anxiety which is an enotional force consciously motivated which results in an overwhelming sonse of fear for which there is no reasonable explanation and, No. 4, phobia, which is due to an unconscious emotional force, but which attaches itself to an external object or situation unrelated to the unconscious anxiety. It is well known that anxiety produces physiological symptoms 
such as precordial pressure, tachycardia, pounding of the heart, shortness of breath, splanchnic tremor, sweating, weakness, and an inability to confront the anxiety-producing situation rationally." [p. 49]

Mowrer (1939) says that, "anxiety is a learned and anticipatory response to cues that have, in the past, been followed by injury or pain." [p. 555]

Krech and Crutchfield (1965) define anxiety as "a state of apprehension by the person in which the source is usually not as specifically perceived as in fear; it often pertains to anticipations of future danger, such as punishment, or threats to self esteem. Anxiety typically leads to defensive reactions intended to allay or avoid the anxiety." [p.310]

On the other hand Mechanic (1962) merely perceives anxiety "as a measure of stress in students." [p. 81]

Cattell (1963) has attempted to define anxiety or an experimental basis. He indicated, "there are several hundred alleged and comnonly accepted manifestations of anxiety and has found their degree of mutual correlation, both in normal population samples, and clinical samples." He has applied the method of factor analysis to answer the question, "are there several anxieties or is there a single, functionally unitary anxiety?" He obtained a "clear experimental answer that there is a single anxiety factor which factor analysis shows to be distinct from the stress response, from a regression pattern, and from certain other components typically found in the total picture of neuroticism." [pp. 101-104] 
However defined, in any actual research project anxiety is defined operationally by the adoption of a particular method of measuring it. In lieu of a theoretical definition of anxiety, the operational definition of anxiety, for the purposes of this study then become the anxiety scores as measured by selected test material.

How Anxiaty is Produced

McKeachie (1951) surveyed the results of sevoral experiments conducted to explore the factor of student anxiety as present in a variety of teaching techniques. He found that the professor is more interested in personal characteristics of his students as a teacher and neglects their needs and perception. The students' anxiety is often heightenod or reduced by the instructor's teaching bahavior. Control of anxiecy is asiest if the student is in a highly structured situation where ho knows exactly what he must do. He found that student anxiety depends on the instructor's teaching ability. Generally spexking, control of anxiety is easiest if the student is in a highly structured situation.

Merton (1957) suggasts "that al1 organizations, including schools, reinforce their nembers to behave in such a manner that fills the professional role the organization is interested in shaping. As an example the medical student, who has no great involvement in his work may do poorly, but he is also more likely to be exempt fron acute distress over his poor performance. There is, so to say, an optimum zone of intensity of motivation. Below the lower limit of this hypothetical zone, the student will not be sufficiently motivated to live up to the requirements of his role; beyond its upper limit, 
he will invest each new situation he faces with undue significance. Students vary in the intensity of their fear of failure and in their capacity to tolerate anxiety and in their responses to anxiety. Apart from this individual variability there is variability to the extent to which schools confront students with stressful situations. The structure of social relations can either reduce or increase anxiety. Under such social conditions, anxious students work on one another to intensify anxieties or vice-versa." [pp. 131-134]

This literature that is directly concerned with school anxiety appears to indicate that various policies or methods of teachers and organizations can heighten or reduce student anxiety. If this study indicates that there is low anxiety it could be attributed to a highly structured situation where student roles and expectations are very clear (McKeachie 1951). On the other hand if there is a high degree of anxiety there will be a higher rate of academic failure and dropouts (Merton, 1957; Mckeachie, 1951).

As can be seen in the literature presented, the studies involving anxiety have been conducted mostly on students in fields of graduate study other than social work. Studies or infornation that have been located do not deal directly with anxiety of students involved in schools of social work. Keeping this in mind it can at best be hypothesized that anxiety effects upon social work graduate students might be similar to students involved in other graduate programs. Attention should be focused upon Mechanic's and Merton's studies as their populations come from other professional graduate programs. It is apparent that research coverage of social work students provides a broad horizon for future research. 
Krech and Crutchfield (1965) point out that anxiety and frustration come from a threat to self-esteem contingent upon the failures of goal-attainment. Goal attainment is often frustrated when particular needs of an individual are not satisfied. A person can also perceive himself as failing, being inferior, incompetent, and weak. Or he may project that other people in his environment see him that way. This type of perception usually results from suffering and loss of self-esteen and prestige. Such threats to an individual create anxiety, frustration, and failure. Such threats among social work students are obvious. Many students have come to school after working in a certain agency for several years. It is common knowledge that not all students graduate. To fail would be a tremendous blow to the person particularly if he recurned to the agency where he was working prior to school. These conditions may tend to produce anxiety lavels among social work students that are higher than among students in other fields.

Mechanic (1962) suggests that ferales and older students tend to report more anxiety than males and younger students. He suggests that students develop techniques of meeting demands from a graduate school; that is, they develop defenses, thus being better able to copo with a situation as they gain experience. In other words, the pxocess of adaptation takes place. Such age and sex differences also have not been studied in a social work student population. 
Statement of the Problem

The problem for this study was to determine (1) the trend of anxiety level of social work students, term by term, over the academic year. (2) The cyclical trend of anxiety level of social work students within each term and (3) the effects of age and sex on level of anxiety anong social work students. 
CHAPTER II

METHODOLGGY

General Design

The design of this study was developed to test four experimental hypotheses. It was the aim of this project to examine the effects of (1) age, (2) sex, (3) time of quarter, and (4) term of academic year on anxiety of the first year students in the School of Social Work. The raw data was obtained from six administrations of an anxiety test. The test was administered to the first year students in the School of Social Work at Portland State University during the 1969-1970 academic year.

Test Materials

Tyne of Test: The IPAT - 8 Parallel Form Anxiety Battery (Scheiex and Catte11, 1960) was selected for use in this study because it provided eight comparable and relatively independent forms for the measurement of anxiety, a feature particularly important for a longitudinal study. It was the only test available having this feature. It was selected despite the fact that it is a relatively new test and has not been axtensively utilized or studied. It was intended for use either with individuals or groups of adults or persons at least 15 years of age.

Scheier and Cattell (1960) have described the test by saying, "Al1 of the seven sub-cests on each form are a verbal type, although the last six are disguised in purpose, relatively difficult to fake, and in this sense 'objective'." [p. 3] He also indicated that where content 
allowed for it, responses were balanced for position and for "yes""no" tendencies. Tests were untimed but each required no more than ten to fifteen minutes.

Description of Content: The number of items in each sub-test range from 4 to 10 , the total being for any form 50 . The following is a list of titles of each sub-test with examples of the items included in each:

(1) Questionnaire items:

Example: I feel grouchy and just do not want to see people

A. Occasiona11y

$B$. In between

C. Rather often

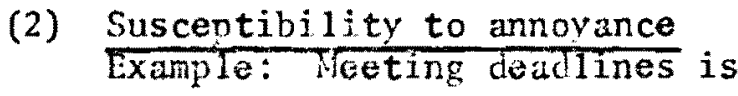

A. Very annoying.

B. Somewhat annoying

C. Not annoying

(3) Lack of confidence in untried ski11s

Example: How much card playing do you do?
A. Never
B. Rare 1y
C. Dccasiona1ly
D. Often

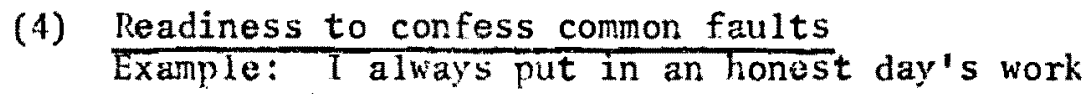
when working for pay.

A. Yes

B. No

(5) Emotionality of comment

Example: The Johnsons are getting a divorce.

A. Too bad. Their fights used to make such wonderful gossip.

B. Neither of them was much of a prize anyhow.

C. Perhaps there is still some chance or a settlement. 
(6) Anxiety-tension symntom; se1f check list.

Example: T have nightmares

A. Less than most

B. Average

C. More than most

(7) Susceptibility to embarrassment. Example: Being laughed at by friends is

A. Not embarrassing

B. Somewhat embarrassing

C. Very embarrassing

Develonment of Test: Scheier and Cattell (1960) derived items from a pool of sixty questionnaires giving some nine hundred anxiety measuring items. From this pool were chosen 350 items for the IPAT 8 Paxallel Form Anxiety Battery.

In a critical review, Cohen and Kjeldergaad (1965) indicated that the IPAT - 8 Parallel Form Anxiety Battery is based on a long research progran involving inudreds of variables of diverse kinds applied to thousands of subjects of varying age, clinical status and background. This program is the consequence of, and feeds back into a detailed theory of the origins, development and structure of personality and motivation. The factor-analytically derived test is simultaneously the product of this rosearch product and its tool.

Although the impressive research background of the test suggested that it would prove valuable for a variety of uses, the inadequate noms and the ambiguity and incompleteness of reliability information limits its use to group results in research studies.

The criticisms of the test are especially relevant where the test is to be used to make judgments on a specific person or a single occasion. These limitations would be of less concern to the researcher making group predictions or in correlational studies, where raw scores would suffice. The basic development of the instrument appears to be 
sound and was based on significant numbers of observations to justify confidence in its potential for use as a research instrument. Scheier \& Cattell (1960) reported that the construct validity, based on a sample of ninety-four undergraduates, ranged between +.53 and +.68 for forms $A$ through $F$. These are correlations, expressed as Pearson's product-moment correlation coefficients, between each form and the anxiety factor. As usual for Cattell, these coefficients represent factor loadings, not correlations with external criteria. He suggested that validity could be improved by simultaneous testing of physiological variables (such as blood pressure, galvanic skin resistance, etc.), but the test makes no special provision for such additional measurements.

Reliability: The inter-form reliability is reported by Cattell and Scheier (1960) to be between +.50 and +.57 for forms $A$ through $F$, while a later study by Bendig (1962) showed them to range from +.60 to +.85 , averaging about +.75 .

Bendig and Bruder (1962) have found that the differences between administrations and the interaction of time intervals in administrations did not approach significance for the battery, and inspection of means gave no evidence of consistent changes in scores between administrations. Of course, the time interval in their study was between two and seven days. The shorter the intervals are between the testing periods the graater would be the apparent reliability. They concluded that the test would be useful for repeated testings in longitudinal studies. 
Scoring and Norms: Scoring was done by hand. This involved summing the weights for each response marked, and obtaining the mean for the items of each section of the test. Sub-test means were then added to give a total score which could range from 0 to 14 . The meaning of the total score is obtained by reference to norms based on 235 cases. The norms were based on the following population:

About five-sixths of the total number of cases comprising the norm sample for any given form are different people, as it is usual in norms, but the remaining one-sixth of cases are repeated administrations of a given form to the same person.... The following demographic background values thus vary slightly between norm samples for each form, but only slightly: average age is 27 to 30 years; average educational level is 11 to 12 years of school completed; about 55 to $60 \%$ of the cases are males. (Scheier \& Cattall 1960)

\section{Administrative Procedures}

The test was usually administered simultaneously to all subjects during a class which all of the first year students attended during the 1969-1970 academic year. The first four forms were administered by individuals other than the authors in order to avoid questions on the nature of the test which should not be disclosed, according to test manual instructions, as this might influence results.

The following instructions wore read to the students on each occasion:

I ask your cooperation in taking the test I am handing out to you. It has no connection with this course and is part of a thesis project here in the School of Social Work.

It is a briaf test. It should take you no more than ten to fifteen minutos to complete.

You are being handed a test booklet and an answer sheet. Please note that on the answer sheet thare is space for your age and sex. Please fill this. You will also note that 
your name is not being asked because the researchers are not interested in identifying you, but only in correlating age and sex to the test scores.

I cannot tell you anything about this study, but at the end of the year, the nature of this test and its results will be made available to you. The test will be administered to you several times during the year.

When you are answering the questions keep in mind the following: 1. Give only one answer to each question. 2. Always answer what is true for you at this moment. 3. Ask me about any word meaning not clear to you. 4. Please, do not mark the booklets. Use the answer sheets to indicate your answers.

Thank you for cooperating in this project.

The test was administared on six occasions over the 1969-1970 school year, during classes with the instructors' permission either at the beginning or the end of the class hour. Foms $\Lambda$ through $F$ of the battery, and in their alphabetical order, were administered on October 21, 1969, December 9, 1969, January 20, 1970, March 10, 1970, Apri1 7, 8, and 9, 1970 and May 25, 26, and 27, 1970.

Two forms of the battery were given during each term. The first "time of quarter" for Fall, Winter, and Spring was twenty to thirty day's from the first day of school; the second "time of quarter" was between the tenth and eleventh week of each term (a term has twelve weeks at Portland State University). The variation was due to scheduling considerations with the instructors.

Variations in Procedure: During the Spring term, it was necessary to give the test to students in three separate sections of the same requirad course. This was because there was no period of time in which all students gathered together during that term. 
Also, due to student resistance to testing, the rationale for keeping the authors anonymous was reconsidered; during the April testing we identified ourselves in order to gain the students' cooperation.

\section{Timing of Test Administration and Associated Events}

Before, during and after each test period, students' reactions were observed and recorded for the duration of this project. Also events of significance that preceded and followed each testing occasion were noted. This record follows here in chronological order. October Administration: (1st Test) October 21, 1969. During the research class on October 17,1969 , a questionnaire was given out to the students. This questionnaire took approximately one and one half hours out of this two hour class. Many of the students questioned the appropriateness of the questions and their role in this thesis project. One student got up and left the room before class ended and slammed the door behind her in what appeared to be her annoyance in this class. There was much talking during this class period between small groups of students even while the instructor was involved in the teaching or lecture process.

Prior to the beginning of the next lecture on October 21,1969 when our first test was given, the following comments were made by several students in the student cafeteria. At this time the students were not aware that they would be asked to take the test. These comments included: "I have never read and read so much without knowing what I have read." "I heard that B was giving a test today." "Did 
you know that there were nineteen F's given in this class last year?" "There is very much disorganization - I can't put things together or find assigned articles."

When the instructor came into the class he told the students that he was going to give them a test on the course matorial and the students became very upset with this. They said that he broke his contract which meant that he had said previously that he would not give a test without previous warning. Because of the commotion by the students the instructor decided that the test would be a take-home. After lecturing for approximately one hour the instructor gave a break at which time it was announced that the students remain in order to await for the administration of another test that was not connected with this particular course. At this time two students left, but then came back following the arrival of the administrator of the anxiety test. Some comments made at this time were "Oh no another test," and as tho test was given "I sure would like to know what this thesis is," "You should have passed out the answer sheet first."

December Administration: (2nd Test) On December 9, 1969 the second test was given. During the week prior to this date the students were involved in their evaluations for their field placements. Also at this time final examinations would be held the following week. The test on the second occasion was given at the beginning of the class. It took approximately twenty-five minutes whereas the first tost took fifteen minutes to administer. The class was very calm and there was no resistance to the tester as in the first test. There was some laughing among several students about questions on the test. 
January Administration: (3rd Test) Tho third test took place on January 20,1970 and as in the second test it was given at the beginning of the class. This test took fifteen minutes for everyone to complete. The previous week at this class there had been an examination given on the course content. The students questioned the instructor at the beginning of the class about whether or not the scoring of this test had been completed but it had not. At this time also voting for class officers was scheduled and took place after the anxiety test was given. After the class, the second meeting of student small groups took place. These groups were formed for the purpose of applying the theory that was being presented at the class where our tests were giver. The students were concerned and resistive to the idea of forming these groups. All of these upconing events were known to the students at the time that our test was being given. Some comments made by students at the time of the testing included "This is an anxiety test" and "Why don't they pay us to take this." The instructor assisted the test administrator because there was a lot of talking among the students and they didn't appear to want to settle down to take it. Some of the students came late to class after the test had started and they questioned both the instructor and the test administrator whether they had to take it or not.

As the students started taking the test, they eventually got very quiet and settled down. Now and then people started to laugh and there were some quiet comments made to other students about some of the questions. 
March Administration: (4th Test) The fourth test took place on March 10, 1970. This was the last class in Human Adaptation where the test would be given to all of the students together. The administrator started giving the test five minutes before the class was due to start and the testing ended twenty minutes later. The class was expecting return of a test which had been administered several weeks earlier on course material, but found out that the instructor would not be returning it until a later date. Many of the people in the class had from three to four papers due by the end of the week plus examinations for the end of the winter term which would be due the following week. One student in the class had dropped out two weeks earlier. This was discussed in some of the classes prior to the one where this test was given. On this date attendance at the class reached its lowest point since the beginning of the year. This was the last class lecture given by one of the instructors. During the testing period the students were very noisy for the first ten minutes. There was a lot of talking and both the instructor and administrator asked the students to take the test without exchanging comments with one another. There was song griping about taking the test by the students but not as much resistance as to some priox tests. April Administration: (5th Test) The fifth test took place on April 7, 8, and 9, 1970. This was the first time that the test was administered to three separate classes because there was no one time when all the students met together. These tests were given at the beginning of the classes. The three classes in which the test was given consisted of the social welfare policy sequence which is a 
required course for all first year students. These classes met on separate days and at different hours. Approximately one third of the students in the class were in each section. Generally the students taking, the test at these times were very quiet and serious compared to the class where the test was given to all of them together. There was some laughing by sone small groups of students, but no visible resentment. One student commented that the test made them angry and hostile and that there was also some encouragement by this student toward the others in his section of the course to not answer the questions consistently. There were also other comments by students questioning the type of test, for example, one student said that this was the MPI Test. This test was given at the beginning of the Spring term. May Administration: (6th Test) The last test was given on May 25, 26, and 27, 1970. Intervening between the previous test and this one, the following events took place: On May 4, 1970 there were four students killed on the Kent State University Campus which triggered serious events at this university, events which also involved students of the School of Social Work. On May 5 th a policy regarding a student strike was issued by the administration of the School of Social Work. On May 6 th there was a national student strike at which time the Portland State University campus was closed and barricades were set up around the university. A School of Social Work Moratorium Committee was mobilized. For the remainder of the school year the students involved in this Committee actively participated in a petition drive to seek support against the war in Viet Nam. The social rork students were given a choice of alternatives: to participate in the petition 
drive, to participate in the Moratorium Committee, or to continue with normal class activities. As the Spring term was drawing to a close many students found out that there was a possibility that their grants would not be continuing on to their second year. This was a result of. a state financial crisis involving the Nelfare Program which many of the students had gotten involved in. Students were also anticipating job opportunities for the forthcoming summer. The sixth test was submitted in the same manner and in the same classes as the fifth test. At this time all of the students were advised that the test was being given by the authors as part of their thesis study.

\section{Subjects}

Population Sampled: First year students of the School of Social Work at Portland State Universicy, during the 1909-1970 academic year, and attending the specific classes where the test was administered provided the initial sample.

The students were asked to identify only their sex and age, but otherwise remain anonymous. This was done because it was felt it would assure better cooperation if it was understood that this research did not involve identifying them as individuals.

The distribution of chronological age of the students ranged between 22 and 49 years of age during the initial testing (October). The median age $(28-1 / 2)$ of this sample was used as the division between the "younger" and "older" groups of students.

Table 1 shows the number of students enrolled at the School of Social Work, the number of the students that were tested, and the number of usable tests. Some tests could not be utilized because some 
students gave no age and/or sex identification on the answer sheet. The same table identifies the number of students classified by age and sex, during each testing occasion.

Sampling Method: From this pool of usable tests twenty subjects ware chosen to represent each testing occasion in the fashion indicated in Table 2. It was decided to limit the sample to five students per cel1 as this was the smallest sub-group of students tested on one occasion. (See Table 1, March testing, Females over 29). This was also decided because equal size samples of five students each significantly simplified the computational procedures involved in the selected method of data analysis. In selecting the subjects, the usable answer sheets were first divided by testing occasion, classified by age and sex, then arranged in order of age and numbered. Tables of random numbers were then used in connection with the indexed numbers in order to select the five subjects to represent each sub-group.

Evaluation of the Samnle: The School of Social Work provided the following data about the enrolled graduate students during the Fall quarter of 1969: 34 male and 34 female students enrolled for that term: 60 were full-time students and the remaining eight wero part-time students. The youngest student was 22 years old and the oldest was 49 , the mean age boing 30 years of age.

The School's information concerning the age of the population sampled agrees fairly well with the mean age, which was found to be $31(30.8)$ years o1d. Table 1 shows that for the October testing no information was obtained on 12 students, most of whom must have been in the "youngex" age group. The number of male and female students 
TABLE 1

Population and Sample

\begin{tabular}{lcccccc}
\hline Testing Time & Oct & Dec & Jan & Mar & Apr & Nay \\
Test Form & A & B & C & D & E & F \\
\hline Students enrolled & 68 & 68 & 66 & 66 & 65 & 65 \\
Students tested & 62 & 58 & 61 & 49 & 54 & 50 \\
Usable tests & 56 & 55 & 58 & 44 & 52 & 48 \\
\hline Males over 29 & 13 & 16 & 14 & 10 & 14 & 11 \\
Males under 28 & 15 & 10 & 13 & 13 & 13 & 14 \\
Females over 29 & 16 & 16 & 17 & 16 & 16 & 10 \\
Females under 28 & 12 & 13 & 14 & 5 & 9 & 13 \\
Total & 56 & 55 & 58 & 44 & 52 & 48 \\
\hline
\end{tabular}

TABLE 2

Final Sample for Statistical Analysis

\begin{tabular}{lcccccc}
\hline $\begin{array}{l}\text { Testing Time } \\
\text { Test Form }\end{array}$ & $\begin{array}{c}\text { Oct } \\
\text { A }\end{array}$ & $\begin{array}{c}\text { Dec } \\
\text { B }\end{array}$ & $\begin{array}{c}\text { Jan } \\
\text { C }\end{array}$ & $\begin{array}{c}\text { Mar } \\
\text { D }\end{array}$ & $\begin{array}{c}\text { Apr } \\
\text { D }\end{array}$ & $\begin{array}{c}\text { May } \\
\text { F }\end{array}$ \\
\hline Males over 29 & 5 & 5 & 5 & 5 & 5 & 5 \\
Males under 28 & 5 & 5 & 5 & 5 & 5 & 5 \\
Females ovor 29 & 5 & 5 & 5 & 5 & 5 & 5 \\
Females under 28 & 5 & 5 & 5 & 5 & 5 & 5 \\
\hline Total & 20 & 20 & 20 & 20 & 20 & 20
\end{tabular}


of the sample was identical, as was the number in the population.

From a statistical point of view one might question the pure randomness of the final sample. Table 1 shows that the population sampled on each testing occasion varied, never including all the enrolled students. This variation occurred for reasons previously explained. The random selection was taken with some of the population missing, thus possibly biasing the representativeness of the selected sample. However, it should be noted that assignment of subjects to the sample did involve an element of random selection. A table showing scores of all students on all variables has been included in the appendix.

\section{Statistical Design}

The analysis of variance permits the simultaneous investigation of all four of the independent variables (sex, age, points in quarters and points in year), in a $2 \times 2 \times 2 \times 3$ factorial design. It is a flexible design suited to the hypotheses as it evaluates the significance of the main variables and checks interaction effects and trends among these variables. In all $\mathrm{F}$ tests the within group variance was used as an estimate of experimental error.

The statistical hypotheses consisted of the following four: (1) There is no age effect on anxiety scores; (2) there is no sex effect on anxiety scores: (3) there is no significant anxiety effect from one period of the quarter to the next ("time of quarter"): and (4) there j.s no "terms in academic year" effect on anxiety scores. 


\section{CHAPTER II I}

\section{RESULTS}

The mean scores showing the general anxiety level for the total sample of social work students on each of the six dates are presented in Figure 1. Numbers graphed in this figure also appear in the "total" row in Table 3. The graph is relatively level, with only slight variations, The mean scores are intermediate, their level of anxiety ranging between 24 th and 46 th percentiles as compared with the normative data (Scheier \& Cattel1, 1960).

Inspection of the graph of Figure 1, as well as the total mean scores of Table 3 show that in all cases, anxiety was higher in the beginning of each term and was less at the end of the term. The highest score for the total group was during the beginning of Fall term and the lowest at the end of Winter quarter. The greatest difference of mean scores occurred in the Fall (.67) while the least occured during Figure 1. Anxiety Scores of $1969-1970$ for the Total Group. $(N=20)$

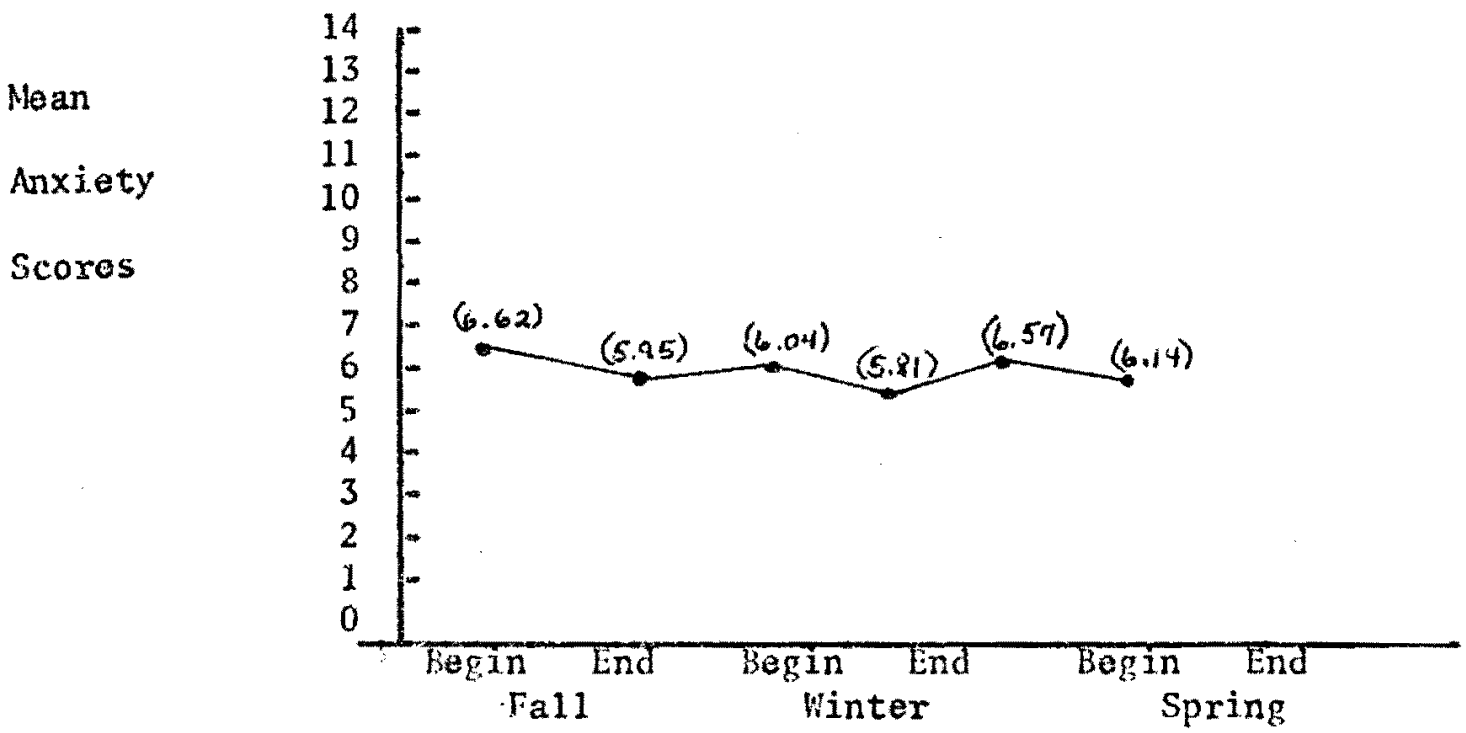


TABLE 3

Hean Anxiety Scores of Subgroups

\begin{tabular}{|c|c|c|c|c|c|c|c|}
\hline & \multicolumn{2}{|c|}{ Fall } & \multicolumn{2}{|c|}{ Winter } & \multicolumn{2}{|c|}{ Spring } \\
\hline & & Begiñ & End & Begin & End & Begin & End \\
\hline \multicolumn{8}{|l|}{ Male } \\
\hline & Younger & 6.62 & 5.66 & 5.94 & 6.19 & 6.92 & 6.49 \\
\hline & older & 6.21 & 6.35 & 5.93 & 6.11 & 5.72 & 5.84 \\
\hline \multicolumn{8}{|c|}{ Female } \\
\hline & Younger & 6.77 & 5.52 & 5.67 & 5.55 & 6.74 & 6.24 \\
\hline & Older & 6.87 & 6.26 & 6.61 & 5.41 & 6.91 & 5.99 \\
\hline Total & Group & 6.62 & 5.95 & 6.04 & 5.81 & 6.57 & 6.14 \\
\hline
\end{tabular}

Winter (.23) with a .43 difference for Spring quarter. As it can be observed in the graph, the mean scores for the total group ranged between 5.81 and 6.62 . Individual test scores ranged between a low of .83 and a high of 8.47 .

Table 3 also shows the mean anxiety scores of each sub-group broken down according to the four variables (age, sex, time of quarter, and terms of academic year). These mean scores vary between a high of 6.92 and a low of 5.41, which indicates that they are clustered. The beginning Fall figures seem to contain the first or second highest figures for each of the four rows. Also, like the graph of Figure 1. Table 3 illustrates a high in the beginning, low at the end of each term pattern, shown by the "total" row figures.

The variable of "time of quarter" (beginning and end) during the year was tested with analysis of variance and the F (see Table 4) was found to be significant at the .05 level. However, none of the 
TABLE 4

Analysis of Variance of Anxiety Test Scores

\begin{tabular}{|c|c|c|c|c|}
\hline Source & $\begin{array}{l}\text { Sum of } \\
\text { Squares }\end{array}$ & d. $f$. & $\begin{array}{c}\text { Mean } \\
\text { Square }\end{array}$ & $F$ \\
\hline A. Sex & .0634 & 1 & .0634 & .0438 \\
\hline B Age & .0017 & 1 & .0017 & .0011 \\
\hline C Time of Quarter & 5.8786 & 1 & 5.8786 & $4.0693 *$ \\
\hline $\begin{array}{c}\text { Derm of Academic } \\
\text { Year }\end{array}$ & 4.2132 & 2 & 2.1066 & 1.4582 \\
\hline$A \times B$ & 2.1493 & 1 & 2.1493 & 1.4878 \\
\hline$A \times C$ & 3.1622 & 1 & 3.1622 & 2.1889 \\
\hline$A \times D$ & 1.1679 & 2 & .5839 & .4041 \\
\hline $\mathrm{BxC}$ & .1043 & 1 & .1043 & .0721 \\
\hline$B \times D$ & 3.4398 & 2 & 1.7199 & 1.1905 \\
\hline $\mathrm{CxD}$ & 1.0076 & 2 & .5038 & .3487 \\
\hline $\mathrm{AxB \times C}$ & 1.2364 & 1 & 1.2364 & .8558 \\
\hline$A \times C \times D$ & .1839 & 2 & .0919 & .0365 \\
\hline $\mathrm{A} \times \mathrm{B} \times \mathrm{D}$ & .4795 & 2 & .2397 & .1659 \\
\hline $\mathrm{BxCxD}$ & 2.6220 & 2 & 1.3110 & .9075 \\
\hline$A \times B \times C \times D$ & .1174 & 2 & .0587 & .0406 \\
\hline $\begin{array}{l}\text { Between Variance } \\
\text { Within Variance } \\
\text { Total Variance }\end{array}$ & $\begin{array}{r}25.8272 \\
138.6878 \\
164.5150\end{array}$ & $\begin{array}{r}23 \\
96 \\
119\end{array}$ & $\begin{array}{l}1.1229 \\
1.4446 \\
1.3824\end{array}$ & \\
\hline
\end{tabular}

* Significant at .05 level 
interactions with this variable were found to be significant. This meant that there was a consistent and significant difference in anxiety level from the beginning to the end of each term. The lack of any significant interaction meant that this effect did not vary for sexes, for persons of different ages, or for different terms of the year.

The same statistical test showed that the "time of year" (Fall, Winter, Spring) did not vary significantly, nor did any of the interaction effects involving the same variable show significant variance. That is there was no trend or variation in anxiety level from quarter to quarter during the year.

Figure 2 - Anxiety Scores for Male and Fenale Subjects

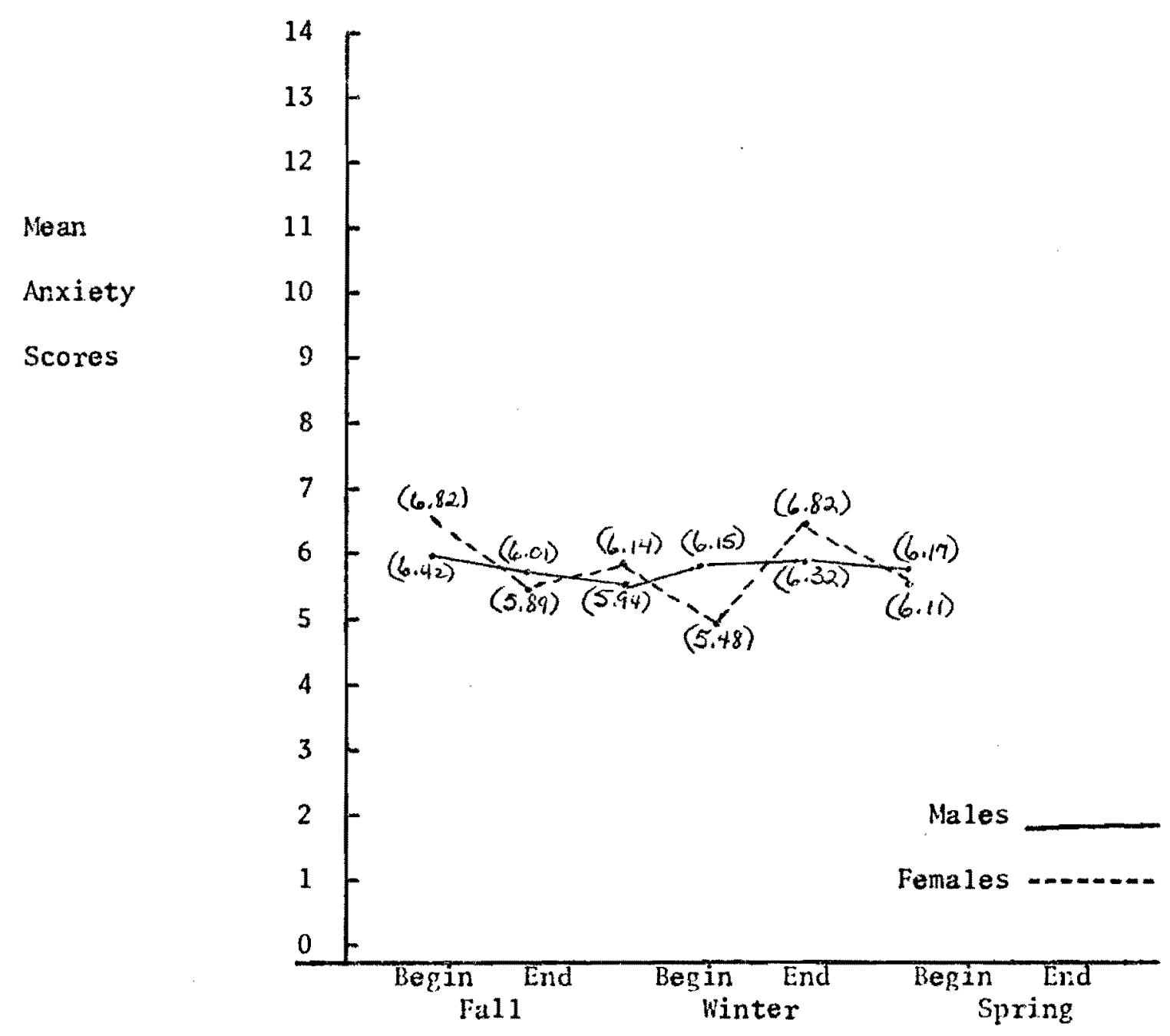


In Figure 2 the mean anxiety scores are presented according to sex. Inspection would suggest that the anxiety of the males fluctuates less than that of the females, generally being almost level. No trend or pattern is obvious with the males. The table of noms shows that the anxiety of male students fluctuates between the 34 th and 53 rd percentiles of the general population.

The fentales' anxiety would appear as more variable in the graph. The difference between the highest and the lowest score for men is .48 while for women it is 1.34 . As compared to the general population, the anxiety level of female subjects ranges between 32 nd to 55 th percentiles, on $1 y 4.5$ percentile points more variant than that of the male subjects. Females consistently seem to follow a pattern which is high in the beginning, low at the end of each term. Women had both the highest and the lowest mean anxiety scores $(6.82$ and 5.48$)$ during the year.

Analysis of variance, however, indicated that the F for the sex variable (see Table 4) did not reach levels of significance, nor did any of the interaction effects involving this variable. This meant that the differences noted between males and females could best be regarded as random sampling variations rather than as true differences.

Figure 3 graphically illustrated the mean anxiety scores according to age group. There did not seem to be a significant variation for either group in terms of anxiety over time; the graph is rolatively level. Comparisons of the lovel of anxiety displayed by this group and the general nomative population show a 26 to 56 percentile range for the younger group, and 28 to 47 percentile range for the older group. 
Figure 3. Anxiety Scores for the Younger and the 01der Groups.

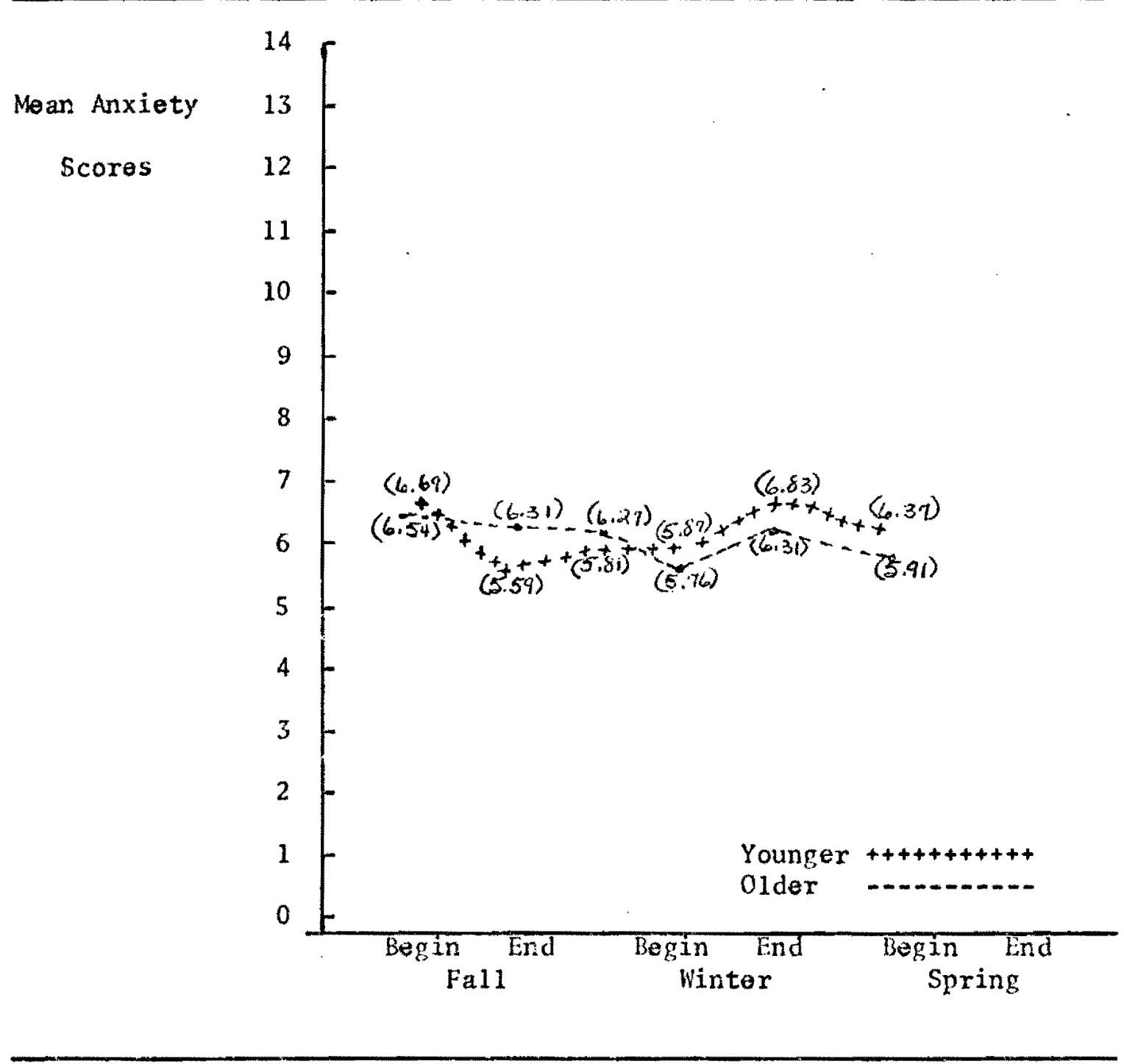

As the percentile norms would lead one to expect, the range of means for the older group appeared to show less variation in anxiety (.78) than the younger group $(1.24)$, a statistically nonsignificant difference (evaluated in tems of the F distribution). The younger group was again shown to display the highest anxiety score $(6.83)$, and the lowest one (5.59). 
The variable of age was found to be statistically nonsignificant (See Table 4). The same was found to be true with any of its interaction effects. Anxiety level, therefore, could not be said to be related to age in this group.

\section{Summary of Findings}

Table 4 summarizes the results of the analysis of variance. Although some variation among the four variables (age, sex, time in quarters, and time in year) and theix interactions was found, only the "time of quarter" effect reached a significant level; a11 other differences may be attributed to random sampling fluctuations. 
CHAPTER IV

CONCLUSIONS

Main Effects

Time of Quarter: The trend of anxiety levels of social work students over the academic year was measured twice each term. Faculty as well as the authors hypothesized that anxiety would be low in the beginning of each term and get higher near the end of each term, as finals approached and assignments were due. This was expected to occur in a cyclical fashion.

Papers and other assignments and examinations would be expected to raise the anxiety level at the end of each term. It was also originally anticipated that these course requirements would probably be met during the latter part of each term. As the school year progressed this time table was not found to be accurate.

At the beginning of Winter term there was a final examination in one of the classes (see account of March administration of test), and term papers wore still expected back from the preceding term. This was a condition tho authors had not foreseen.

In fact, a significant high in the beginning - low at the end of each term trend was observed to occur each term instead of the low in the boginning - high at the end of each term pattern that had been predicted by the authors and by the faculty.

It may be conjectured that as the term went on, students found that their expected duties bacame better defined, which probably 
lessened the anxiety level during the second "time of quartor." Possibly the novelty of the classroom situation contributed to anxiety in the beginning of each quarter; anxiety subsided however, as tasks and expectations became clearer and faniliarity increased with the routine of that term.

Term of Academic Yeax: It was hypothesized that anxiety would be reduced with time as the students met and coped with the new situation in graduate school. Mechanic (1962) and Merton (1957) indicated that the process of adaptation would affect how students deal with anxiety. They said that with time the student would develop more successful ways of dealing with it and channeling it in constructive ways,

This ordglinl hyothesis was somewhat umended following the occurrence of events that had not been anticipated. The intense student participation and interest in campus deronstrations and other related activities brought about by the national student unrest following Kent State events (see Test Administration and Associated Events section) were expected to raise the anxiety levels of the subjects of this study. Nlso, the selection and assignment of thesis or practicums during the Spring term by the students was expected to be a significant producer of anxiety. Therefore, anxiety was expected to be high during the Fall term, being at its lowest during the Winter term, and high again during the Spring.

However, this trend was not observed that academic yoar. Such a phenomenon might be explained partially by the various altematives that the School of Social Work offered its students luring Spring 
term (participation in either a petition drive, or the moratorium committee activities, or attend classes as usual). These might have met the students' individual needs, thus offsetting the hypothesized increases in anxiety levels.

Age: It was anticipated that anxiety scores of the older students (over 29) would be significantly higher than those of the younger students (under 28). This hypothesis was also based on Mechanic's study (1962).

The effect of age on the level of anxiety among the School of Social Work students was not significant.

One might speculate that there were counterbalancing forces at work between age groups that account for the lack of age effects. For example, older students might have felt anxious because of their apprehension about competing with those just out of undergraduate study. Younger students might have felt anxious because of having to compete with students already experienced in the field.

The above suggests another variable to be included in future studies, that of "background" of the individual student prior to entering graduate school.

Sex: The expectation was that female students would generally report higher anxiety than male students. This expectation was based on Mechanic's study (1962) of medical students. However, no such significant difference was found to be affected by sex.

These findings do not account for the lack of a sex effect. In considering the differences in results of this study as compared with those of Mechanic, it may be hypothesized that (1) the social work 
female graduate students were not typical of all graduate school females: (2) social work female graduates are atypical of other female students in other schools of social work; or (3) the female students in social work differ from female medical school students. Such differences could be tested by repeating this project in other schools of social work and/or in other graduate school departments.

Interaction Effects: As indicated in the Results chapter, no interaction effects were found to reach significant levels of variance. The authors had no specific hypotheses in mind concerning interaction effects. Therefore, no further discussion of interactions seems necessary.

Discussion of the Research Method: The possibility of replicating this study has often been suggested, with the addition of new variables.

In simply attempting to get at the same kinds of data that these authors were interested in, the following suggestions would possibly improve the method of obtaining data.

In order to know whether you test the same person each time some type of identification procedure would be recommended. This constant identified sample could possibly assure more accurate data. The sampling method could be simplified by randomly selecting a number of students who would consistently take the tests at the designated times through the year, taking into account representation of students interested in casework, group work and community organization or those undecided. This may provide more continuity and would 
prevent the switching population, and the scoring of more than the needed number of answer sheets.

It would also be desirable to control for the setting and the test administrator's effect on the students tested, by keeping both constant. Preferably the testing should be given without the benefit of other interests or obstructions at the time of testing, such as other classes, lunch periods, breaks, etc. In other words, the monitor should have full control and attention of the tested group. The time of day, should also be kept constant, if possible, to avoid variation effects on anxiety scores.

At this time the IPAT -8 Parallel Form Anxiety Battery was the only test available and appropriate for our study. Further investigation may reveal a better research tool, or this may become another thesis project in itself, becauss of the questionable reliability and undemonstrated validity of the one used.

The time interval between tests could provide varying data which, if gathered more frequently, would give a more detailed picture of the pattern of anxiety through the year.

Galiardi (1960) says that those students who have definite vocation plans after graduation (that is, their plans for employment are definite) will have less anxiety than students who have not made a definite plan. This suggests another variable to considor.

Discussion of Effects: There was a cyclical pattern of anxiety that occurred each tern. This statistically significant pattem followed a high-low instead of a low-high trend. The predicted lowhigh trend was based on the incorrect assumption that anxiety would 
be raised as a result of periods of examinations, and field evaluations which usually took place at the end of each term. According to the observations of the authors what seemed to elicit a greater amount of anxiety in students was the uncertainty, the need to acquaint onese $1 f$ with the course requirements and generally an effort to find bearing and direction. In other words, the factor which seemed to be most critical was the newness of the situation each term.

The above observation ties up with the finding that the anxiety level remained quite level over the academic year. It seemed that there was no generalized leaming that would help the individual better cope with anxiety the following term. Therefore, it can be speculated that the high levels of anxiety that were elicited were intrinsically associated with the newness of each term and could be characterized as situational.

The students in the School of Social Work responded to anxiety as a total group. No significant sex or age differences were registered in the findings. It may be hypothesizod that their role as "social work graduate students" was a powerful common denominator that influenced the behavior of individuals in the same direction. External events seemed to have little effect unless they related to that role. 


\section{CHAPTER V}

\section{SUMMARY}

The study was made of anxiety of graduate students in social work by testing anxiety levels on six separate occasions during the 1969-1970 academic year. The results were analyzed according to time of quarter, term of academic year, sex and age.

From these findings, four conclusions were reached. The most surprising finding was that each term, and throughout the academic year a high-low trend of anxiety was observed, contrary to the expectation of a low-high pattern. It may be speculated that the uncertainty of a new situation created more anxiety than did the final field evaluations and classroom examinations. A more stmactured program in the beginning of each term may be expected to lessen the amount of anxiety at that time.

The anxiety level remained the same throughout each term of the academic year. It seens that oven such powerful external events, such as the Kent State demonstrations did not effect the level of anxiety of the students; the greatest impact seemed due to events within the program of the Schonl of Social Hork (as revealed by the quarterly sequence already mentioned).

The effect of age on the level of anxiety among students was not significant, unlike the authors' expectations. It was felt that variations in the students' backgrounds associated with age differences prior to entering the School of Social Work, might result in greater variations in anxiety. 
Finally, the sex effect, contrary to the original hypothesis, was also insignificant. Nnticipated higher anxiety of females was not observed, a result inconsistent with findings previously reported by other investigators.

It was suggested that further research on anxiety of social work students be continued; specifically, that experimentation on the effect of differing degrees of structure in classroom and fiald work be considered. It was also suggested that the previous experiences and background factors of social work students be studied for its effects on mxiety. Finally, alternate research methods that provide for a better controlled selection of a sample and more frequent testing ware also suggested. 


\section{REFERENCES}

Alpar, Thelma S. Memory for completed and incompleted tasks as a function of personality: An analysis of group data. J. Abnorm. Soc. Psychol., 1946, 41, 403-421.

Apicella, F. S, and AcClelland, D. C., Reminiscence following experimentally induced failure. J. Fxp. Psychol., 1947, 37, $159-169$.

Bendig, A. W., and Bruder, Gail, "The Effect of Repeated Testing on Anxiety Scale Scores." J. of Cons. Psych., Aug. 1962, Vol. 26, No. 392 .

Bendig, A. W., and Hountras, P. T., "Anxiety, Authoritarianism and Student Attitude Toward Departmental Control of College Instruction." J. Ed. Psych. 1959, 50, 1-7.

Buss, Amold, Psychonathology, Naw York, London, Sidney: John Wiley and Sons Inc., 1966, pp 50-57.

Catte11, Raymond B., "The Nature and Measurament of Nnxiety," Scientific American, March 1963, 96-104.

Cohen, Jacob, Review of Inat - 8 Parallel Form Auxiety Battery, in Buros $0 . \bar{K}$. Editor, The Sixth Tental Wasurements Year kook, Grypion Press, Highland Park, New Jersey 1965, 124-125.

Farber, J.E., and Spence, K. W., Complex Learning and Conditioning as a Function of Anxiety. J. Exp. Psychol., 1953, 45, 120-125.

Galiardi, Roman S., O.S.B. Adjustment and Anxiety as Related to Vocational Choice, Catholic University Press, Washington, D.C. * $1960, v_{4} 8,130-144$.

Grooms, R. R., and Endler, N. S., "The Effect of Arxjety on Acadenic Achievement," J. Ed. Psych., 1960 (51) 299-304.

Krech, David, ard Crutchfield, Richard, Elements of Psychology, Kroph, New York 1965, Chap. 11, 29

Kjeldergaaxd, Paul M. Review of Inat - 8 Parallel Form Anxiety Battery, in Buros $0 . K$. Editor, The Sixth Mental Measurenanic Year Book, Cryphon Press, Highland Park, New Jersey 1965, 124-125. 
Lantz, Beatrice, Some Dynamic Aspects of Success and Failure., Psychol. Monogr.. 1945, 59, No. 1 (Whole No. 271).

McKeachie, W. J., "Anxiety in the College Classroom," J. Ed. Res., $1951,45,153-160$.

Mckinney, F., Certain Emotional Factors in Learning and Efficiency., J. Gen. Psychol., 1933, 9, 101-116.

Mechanic, David, Students Under Stress, (New York: The Free Press of Glencoe, 1962,79-116).

Merton, Robert K., The Student Physician, Univ. Press, Cambridge, Mass, $1957, \overline{124-188 .}$

Montague, E. K., The Role of Anxiety in Serial Rote Learning., J. Exp. Psycho1., 1953, 45, 91-96.

Mowrer, 0. H., A Stimulus-Response Analysis of Anxiety and Its Role As A Reinforcing Agent., Psychol. Rev,, 1939, 46, 553-565.

Postman, Leo and Bruner, J. S., "Proception under Stress," Psychological Review, 55, 314-323, 1948 .

Raymond, C. K., Anxiety and Task as Determiners of Verbal Perfornance, J. Exp. Psychol., 1952, 46, 120-124.

Sagebiel, James, M. D., "What Is Anxiety," Nn. Med. Assn. Journal, Vol. $188-4-20-64, \mathrm{p}, 49$.

Sears, R. R., Initiation of the Repression Sequence by Experimental Failure, J. Exp. Psychol., 1937, 20, 570-580.

Scheier I. H., and Catte11, R. B., Ipat - 8 Parallel Form Anxiety Battery, Chanpaign, Illinois: Institute for Personality and Ability Testing $1960,1-8$.

Spielberger, Charles D., "The Effects of Manifest Anxiety on Academic Achievement of College Students," Ment. Hyg., N.Y. 1962 420-426.

Tolman, E. C., Cognitive Maps in Rats and Men, Psychol. Rev., 1948, 55 $189-208$.

Williams, M., An Experimental Study of Intellectual Control Under Stress, J. Consult. Psycho1., 1947, 11, 21-29. 
APPENDIX

COMPLETE DATA ON STUDENTS TESTED1

\begin{tabular}{|c|c|c|c|c|c|c|}
\hline Sax & Age & Score & FORM A & Sex & Age & Score \\
\hline M & 26 & 7.46 & & $M$ & 24 & 5.07 \\
\hline$M$ & 25 & 7.20 & & $M$ & 26 & 4.73 \\
\hline$M$ & 25 & 6.92 & & $M$ & 29 & 7.94 \\
\hline$M$ & 28 & 6.39 & & $M$ & 44 & 7.50 \\
\hline$M$ & 22 & 5.14 & & M & 30 & 6.80 \\
\hline$M$ & 33 & 8.34 & & $M$ & 38 & 6.77 \\
\hline $\mathrm{M}$ & 29 & 7.06 & & $M$ & 30 & 5.74 \\
\hline$M$ & 29 & 6.68 & & $M$ & 32 & 5.72 \\
\hline$M$ & 48 & 6.16 & & $M$ & 29 & 5.72 \\
\hline$M$ & 31 & 2.83 & & $M$ & 41 & 5.24 \\
\hline F & 22 & 8.56 & & $F$ & 28 & 8.33 \\
\hline $\mathrm{F}$ & 22 & 7.35 & & $F$ & 26 & 8.01 \\
\hline $\mathrm{F}$ & 28 & 6.81 & & $\mathrm{~F}$ & 24 & 7.51 \\
\hline $\mathrm{F}$ & 26 & 6.42 & & $\mathrm{~F}$ & 25 & 7.32 \\
\hline$F$ & 24 & 4.70 & & $\mathrm{~F}$ & 28 & 6.71 \\
\hline $\mathrm{F}$ & 39 & 8.47 & & $F$ & 27 & 4.77 \\
\hline $\mathrm{F}$ & 30 & 6.88 & & $\mathrm{~F}$ & 22 & 4.44 \\
\hline$F$ & 37 & 6.57 & & $F$ & 35 & 7.92 \\
\hline $\mathrm{F}$ & 43 & 6.23 & & $F$ & 31 & 7.53 \\
\hline$F$ & 49 & 6.22 & & $\mathrm{~F}$ & 35 & 7.35 \\
\hline$M$ & 25 & 7.65 & & $\mathrm{~F}$ & 36 & 6.89 \\
\hline$M$ & 22 & 7.37 & & $\mathrm{~F}$ & 48 & 6.66 \\
\hline M & 22 & 7.18 & & $F$ & 34 & 6.28 \\
\hline$M$ & 26 & 6.35 & & $F$ & 33 & 6.16 \\
\hline$M$ & 25 & 6.69 & & $\mathrm{~F}$ & 29 & 5.71 \\
\hline$M$ & 23 & 5.46 & & $\mathrm{~F}$ & 37 & 5.61 \\
\hline$M$ & 26 & 5.17 & & $\mathrm{~F}$ & 48 & 4.83 \\
\hline$M$ & 23 & 5.14 & & $\mathrm{~F}$ & 33 & 4.37 \\
\hline
\end{tabular}

Irirst 20 listed for each form constituted the random sample dratm for that form and date (s). Answer sheets providing incomplete data (no age and/or sex identification) are not included. 


\begin{tabular}{|c|c|c|c|c|c|c|}
\hline Sex & Age & Score & FORM B & Sex & Age & Score \\
\hline$M$ & 24 & 6.13 & & $M$ & 30 & 4.78 \\
\hline$M$ & 24 & 5.97 & & $F$ & 22 & 6.45 \\
\hline$M$ & 24 & 5.95 & & $F$ & 25 & 6.40 \\
\hline M & 25 & 5.67 & & $F$ & 25 & 5.57 \\
\hline$M$ & 22 & 4.58 & & $F$ & 23 & 4.80 \\
\hline M & 29 & 8.44 & & $F$ & 27 & 4.36 \\
\hline M & 34 & 7.59 & & $F$ & 35 & 7.47 \\
\hline M & 37 & 6.00 & & $F$ & 35 & 6.70 \\
\hline M & 33 & 4.95 & & $F$ & 39 & 6.66 \\
\hline$F$ & 36 & 6.01 & & $F$ & 28 & 6.43 \\
\hline $\mathrm{F}$ & 47 & 4.46 & & F & 28 & 6.16 \\
\hline$M$ & 23 & 7.82 & & $F$ & 25 & 6.00 \\
\hline$M$ & 26 & 7.37 & & $F$ & 22 & 5.90 \\
\hline$M$ & 28 & 6.88 & & $\mathrm{~F}$ & 22 & 5.42 \\
\hline$M$ & 26 & 6.54 & & $\mathrm{~F}$ & 22 & 5.18 \\
\hline$M$ & 23 & 3.94 & & $\mathrm{~F}$ & 25 & 5.05 \\
\hline$M$ & 31 & 8.60 & & $\mathrm{~F}$ & 37 & 8.20 \\
\hline$M$ & 29 & 7.68 & & $\mathrm{~F}$ & 31 & 7.78 \\
\hline$M$ & 30 & 7,62 & & $\mathrm{~F}$ & 30 & 6.12 \\
\hline$M$ & 43 & 7.27 & & F & 49 & 6.02 \\
\hline$M$ & 48 & 7.16 & & $\mathrm{~F}$ & 31 & 5.63 \\
\hline$M$ & 38 & 6.10 & & $\mathrm{~F}$ & 37 & 5.29 \\
\hline$M$ & 30 & 5.93 & & $\mathrm{~F}$ & 43 & 5.26 \\
\hline$N$ & 32 & 4.86 & & $F$ & 31 & 5.21 \\
\hline$M$ & 30 & 4.50 & & $\mathrm{~F}$ & 38 & 4.98 \\
\hline$M$ & 32 & 4.34 & & $\mathrm{~F}$ & 33 & 4.29 \\
\hline$M$ & 41 & 2.99 & & $\mathrm{p}$ & 33 & 4.11 \\
\hline$F$ & 24 & 8.20 & & & & \\
\hline
\end{tabular}




\begin{tabular}{|c|c|c|c|c|c|c|}
\hline Sex & Age & Score & FORM C & Sex & Age & Score \\
\hline$M$ & 23 & 6.75 & & $M$ & 25 & 8.17 \\
\hline$M$ & 24 & 6.58 & & $M$ & 22 & 6.98 \\
\hline$M$ & 26 & 6.40 & & $M$ & 24 & 6.27 \\
\hline$M$ & 22 & 6.25 & & $M$ & 28 & 6.13 \\
\hline$M$ & 24 & 3.73 & & $M$ & 26 & 5.90 \\
\hline$M$ & 29 & 8.15 & & $M$ & 23 & 5.30 \\
\hline$M$ & 34 & 7.28 & & $M$ & 25 & 5.21 \\
\hline$M$ & 30 & 5.59 & & $M$ & 26 & 4.19 \\
\hline $\mathrm{M}$ & 40 & 4.44 & & $M$ & 33 & 9.85 \\
\hline$M$ & 31 & 4.19 & & $M$ & 29 & 8.56 \\
\hline$F$ & 25 & 6.68 & & $\mathrm{M}$ & 32 & 7.11 \\
\hline $\mathrm{F}$ & 22 & 5.85 & & $M$ & 30 & 7.03 \\
\hline $\mathrm{F}$ & 22 & 5.62 & & $M$ & 47 & 6.99 \\
\hline $\mathrm{F}$ & 23 & 5.59 & & $M$ & 31 & 6.64 \\
\hline$F$ & 23 & 4.62 & & $M$ & 45 & 5.96 \\
\hline $\mathrm{F}$ & 38 & 8.02 & & $M$ & 38 & 5.41 \\
\hline $\mathrm{F}$ & 29 & 6.84 & & $M$ & 37 & 4.77 \\
\hline $\mathrm{F}$ & 30 & 6.63 & & $M$ & 28 & 8.34 \\
\hline $\mathrm{F}$ & 35 & 6.63 & & $M$ & 23 & 7.41 \\
\hline$F$ & 47 & 4.94 & & $M$ & 28 & 7.11 \\
\hline $\mathrm{F}$ & 28 & 7.10 & & $F$ & 31 & 6.86 \\
\hline $\mathrm{F}$ & 26 & 6.12 & & $\mathrm{~F}$ & 49 & 6.36 \\
\hline $\mathrm{F}$ & 22 & 4.52 & & $\mathrm{~F}$ & 30 & 6.33 \\
\hline $\mathrm{F}$ & 28 & 4.31 & & $\mathrm{~F}$ & 49 & 5.96 \\
\hline F & 25 & 4.02 & & $\mathrm{~F}$ & 43 & 5.90 \\
\hline$\vec{F}$ & 26 & 3.21 & & $\mathrm{~F}$ & 34 & 5.59 \\
\hline $\mathrm{F}$ & 35 & 8.20 & & $\mathrm{~F}$ & 33 & 5.33 \\
\hline$F$ & 37 & 8.13 & & $F$ & 33 & 3.80 \\
\hline $\mathrm{F}$ & 39 & 7.86 & & $\mathrm{~F}$ & 37 & 3.42 \\
\hline
\end{tabular}


FORM D

\begin{tabular}{|c|c|c|c|c|c|}
\hline Sex & Age & Score & Sex & Age & Score \\
\hline$M$ & 24 & 8.23 & $M$ & 25 & 6.04 \\
\hline$M$ & 26 & 6.48 & $M$ & 24 & 5.72 \\
\hline$M$ & 25 & 6.03 & $M$ & 26 & 5.62 \\
\hline M & 22 & 5.42 & $M$ & 24 & 5.57 \\
\hline$M$ & 25 & 4.77 & $M$ & 26 & 5.56 \\
\hline$M$ & 33 & 8.02 & $M$ & 23 & 3.93 \\
\hline$M$ & 29 & 6.36 & $M$ & 29 & 7.08 \\
\hline$M$ & 30 & 6.23 & $M$ & 32 & 5.39 \\
\hline$M$ & 30 & 5.96 & $M$ & 37 & 5.34 \\
\hline$M$ & 30 & 3.97 & $M$ & 31 & 4.65 \\
\hline F & 25 & 6.57 & $M$ & 41 & 3.73 \\
\hline $\mathrm{F}$ & 22 & 5.75 & $F$ & 35 & 7.91 \\
\hline$F$ & 28 & 5.43 & $F$ & 31 & 7.46 \\
\hline F & 27 & 5.25 & $\mathrm{~F}$ & 43 & 6.89 \\
\hline $\mathrm{F}$ & 22 & 4.78 & $F$ & 39 & 6.62 \\
\hline$F$ & 35 & 6.29 & $\mathrm{~F}$ & 28 & 6.52 \\
\hline $\mathrm{F}$ & 49 & 6.21 & $F$ & 49 & 6.10 \\
\hline $\mathrm{F}$ & 34 & 5.09 & $\mathrm{~F}$ & 30 & 5.85 \\
\hline$F$ & 48 & 4.89 & $F$ & 28 & 5.84 \\
\hline $\mathrm{F}$ & 37 & 4.57 & $\mathrm{~F}$ & 30 & 5.15 \\
\hline$M$ & 22 & 7.84 & $F$ & 31 & 5.04 \\
\hline$M$ & 28 & 6.25 & $F$ & 33 & 4.98 \\
\hline
\end{tabular}


FORM E

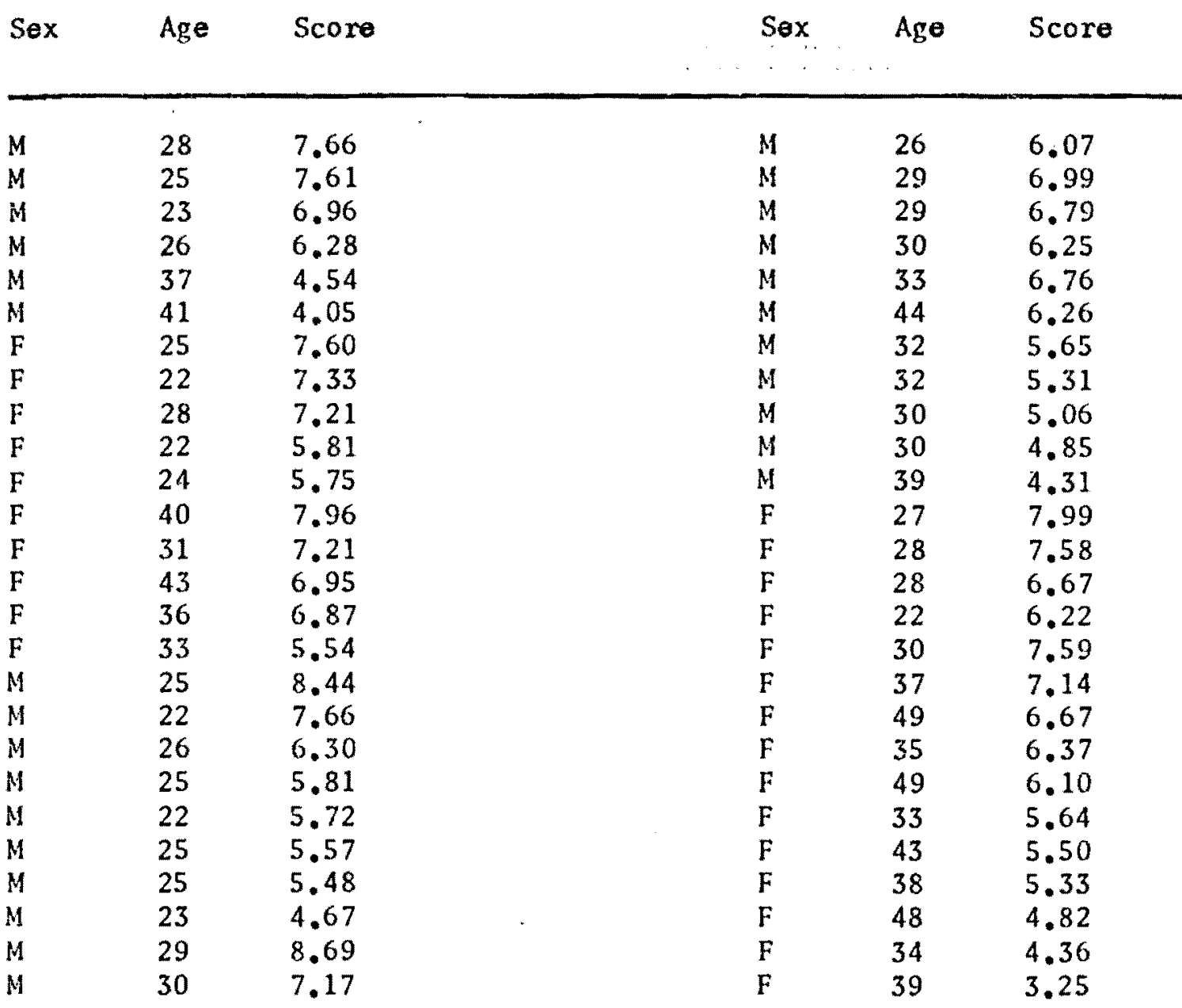




\section{FORM F}

\begin{tabular}{|c|c|c|c|c|c|}
\hline Sex & $\Lambda g e$ & Score & Sex & Age & Score \\
\hline M & 22 & 7.74 & $M$ & 25 & 5.99 \\
\hline$M$ & 26 & 6.48 & $M$ & 26 & 5.88 \\
\hline$M$ & 26 . & 6.19 & $M$ & 28 & 5.49 \\
\hline$M$ & 24 & 6.15 & $M$ & 27 & 4.87 \\
\hline $\mathrm{M}$ & 26 & 5.91 & $M$ & 22 & 4.84 \\
\hline$M$ & 29 & 8.29 & $M$ & 29 & 7.23 \\
\hline$M$ & 33 & 7.28 & $M$ & 48 & 6.49 \\
\hline$M$ & 32 & 5.70 & $M$ & 44 & 5.90 \\
\hline$M$ & 31 & 4.37 & $M$ & 30 & 5.59 \\
\hline$M$ & 37 & 3.55 & $M$ & 31 & 4.54 \\
\hline $\mathrm{F}$ & 28 & 7.57 & $M$ & 41 & $4 . \tilde{34}$ \\
\hline $\mathrm{F}$ & 24 & 6.92 & $\mathrm{~F}$ & 28 & 7.90 \\
\hline$F$ & 27 & 6.50 & $F$ & 28 & 6.13 \\
\hline $\mathrm{F}$ & 25 & 5.79 & $F$ & 23 & 6.09 \\
\hline$F$ & 22 & 4.41 & $F$ & 24 & 6.03 \\
\hline $\mathrm{F}$ & 37 & 6.94 & $\mathrm{~F}$ & 28 & 5.89 \\
\hline $\mathrm{F}$ & 49 & 6.27 & $\mathrm{~F}$ & 43 & 7.72 \\
\hline $\mathrm{F}$ & 31 & 6.23 & $\mathrm{~F}$ & 49 & 7.59 \\
\hline F & 35 & 5.66 & $\mathrm{~F}$ & 31 & 5.82 \\
\hline $\mathrm{F}$ & 36 & 4.84 & $\mathrm{~F}$ & 38 & 5.81 \\
\hline$M$ & 23 & 8.78 & $F$ & 40 & 5.46 \\
\hline$M$ & 26 & 6.79 & $\mathrm{~F}$ & 39 & 4.93 \\
\hline$M$ & 25 & 6.55 & $\mathbf{F}$ & 33 & 4.85 \\
\hline$M$ & 25 & 6.26 & $\mathrm{~F}$ & 48 & 3.84 \\
\hline
\end{tabular}

